INTRODUCTORY ECONOMICS COURSE COMPANION 


\section{INTRODUCTORY \\ ECONOMICS COURSE \\ COMPANION}

Barry Harrison 
All rights reserved. No reproduction, copy or transmission of this publication may be made without written permission.

No paragraph of this publication may be reproduced, copied or transmitted save with written permission or in accordance with the provisions of the Copyright, Designs and Patents Act 1988, or under the terms of any licence permitting limited copying issued by the Copyright Licensing Agency, 90 Tottenham Court Road, London W1P 9HE.

Any person who does any unauthorised act in relation to this publication may be liable to criminal prosecution and civil claims for damages.

First published 1993 by

THE MACMILLAN PRESS LTD

Houndmills, Basingstoke, Hampshire RG21 2XS

and London

Companies and representatives

throughout the world

ISBN 978-0-333-57913-8

ISBN 978-1-349-13004-7 (eBook)

DOI 10.1007/978-1-349-13004-7

A catalogue record for this book is available from the British Library:

Copy-edited and typeset by Povey-Edmondson Okehampton and Rochdale, England 


\section{CONTENTS}

\section{Acknowledgements}

Preface

An Introduction to Study Skills

1 What is economics?

2 The tools of economic analysis

3 Demand, supply and market price

4 The price mechanism and market failure

5 Some applications of price theory

6 The basis of demand

7 The laws of returns

8 Costs and revenue

9 The finance of industry

10 Perfect competition

11 Monopoly

12 Price discrimination

13 Imperfect competition

14 Labour

15 Enterprise

16 Land and capital

17 The distribution of factor incomes

18 National income and its measurement

19 The determination of national income

20 National income determination: the foursector economy

21 Investment

22 Aggregate demand and aggregate supply

23 Money and the creation of bank deposits

24 The monetary sector

25 Monetary control

26 Interest rates

27 Measuring changes in the value of money

28 Inflation

29 Rational expectations in economics

30 International trade

31 Free trade and protection

32 The balance of payments vi

vii

ix
33 Exchange rate systems 193

34 Europe's economic community 203

35 Public finance and taxation 212

36 Stabilisation policy 219

37 Supply-side policies in the UK 223

38 Development and the problems of the less developed countries

Index 


\section{ACKNOWLEDGEMENTS}

The author and publishers are grateful to the following for permission to reproduce copyright material:

Barclays Bank plc for material on page 191.

Daily Mirror for extract on page 71.

Economica for Figure 28.5 form A.W. Phillips, 'The relationship between unemployment and the rate of change of money wages in the UK, 1861-1957', 1958.

Financial Times for extracts on pages 63, 198-9, 230-1.

The Guardian for extracts on pages 88 and 190 .

The Controller of Her Majesty's Stationery Office for Tables 2.1, 17.1, 21.2, 27.2, 28.1 and 32.1 and

Figures 2.1 and 2.2 .

IEA for Table 2.3.

Longman Publishers plc for material on pages 13-15. The Times Newspapers plc for material on page 187 . UNIDO for Table 30.7 .

Western Mail for material on page 77.
They would also like to thank the following examination boards for permissions to reproduce examination questions, though the boards do not take any responsibility for the answers provided by the author:

Associated Examining Board

Joint Matriculation Board

Northern Ireland Schools Examination and Assessment Council

University of Cambridge Local School Examining Syndicate

University of London School Examining Board

Every effort has been made to contact all the copyright-holders, but if any have been inadvertently overlooked the publishers will be pleased to make the necessary arrangement at the first opportunity. 


\section{PREFACE}

This book is designed as a course companion for those studying 'A'-level Economics and equivalent courses. The aim is not to provide a substitute for a main course text. Rather the aim is to provide an introduction to the different topics in the syllabus, to identify the most common errors and to provide practice at answering questions so that understanding of the subject will be improved. It is hoped that by supplementing the information given in conventional textbooks economic awareness will be increased, and that this will be reflected in higher assignment marks throughout the course and in an improved examination performance.

Each chapter follows the same pattern. A topic summary provides the essential outline of the most important concepts, ideas and relationships associated with each topic on the syllabus. This will introduce readers to the subject-matter of the topic. The concise nature of the topic summaries will appeal to students who require more information on topics they have read about elsewhere, or who require a brief, but thorough, grounding in the topic before moving on to a more advanced treatment. The topic summaries are written so as to be accessible to students of all abilities.

Each chapter also contains detailed information on mistakes most commonly made, particularly by students new to the subject. Often basic concepts are mistaken for one another and the section 'Common Mistakes to Avoid' in each chapter identifies those concepts which are commonly confused and explains the differences between them.

In the section 'Questions and Answers' we give answers to typical examination questions. All types of examination question, multiple-choice, data response and essay, are included throughout the book and most of the questions are taken from past examination papers. Full and complete answers are given to each question and in total there are over 75 examination-type questions and answers. While I am grateful to the examination boards for permission to reproduce their questions, they are not necessarily in agreement with the answers given here and they accept no responsibility for them.

Nevertheless, it is hoped that students will find the questions and answers helpful, but, remember, all examiners know that any particular question can often be answered in a variety of ways and no claim is made here that the answers given in this book are definitive. It is certainly not recommended that they be learned by rote in the hope that they reappear on an examination paper. The aim of including answers in this book is to show one way in which each of the questions can be answered and to give an indication of the standard required to achieve success in the examination. It is hoped that having seen examples of good work students will aim to achieve and better the standard set here.

In addition to examination-type questions and answers, this book contains over 220 'Review Questions and Answers' designed to probe and test understanding of each topic on the syllabus. The review questions are reproduced from the core textbook Introductory Economics (Barry Harrison, Charles Smith and Brinley Davies, Macmillan, 1992), and, while some of these questions were constructed by my co-authors of that book, the answers given here are my own work.

Many people have worked long and hard in the production of this book, and if I do not mention them all by name I am nevertheless grateful to them. As always, my wife Lea, and sons, Paul, Matthew and Simon, have provided a great deal of help, advice and support which all authors need. When I wrote my first book my eldest son had not started school and my youngest son was not even born. They are all now old enough to help with the humdrum chores around the house and while they might not always like sharing them, they are at least cheerful about doing them. Again I am grateful to the entire team at Macmillan but must make special mention of my publisher, Stephen Rutt, who has been a constant source of guidance and encouragement. I must also thank Keith Povey and his editorial team for remov- 
ing many errors from my typescript and for transforming it into a version fit for the printer. Finally I have received helpful advice and comments on each chapter from Stan Goodman of Rickmansworth School, Hertfordshire, Phyllis Palmer of Dinnington Comprehensive School, Sheffield, and John Wigley of
Haberdashers' Aske's School, Elstree. All of those mentioned above have suggested many improvements to the text, but as I have not always accepted their advice I am unable to implicate them in any errors or omissions that remain. 


\section{AN INTRODUCTION TO STUDY SKILLS}

Learning how to study effectively is an important skill to develop if knowledge and understanding of a subject are to grow. This introductory section sets out some general points of good practice.

\section{Reading and Note-taking}

There are different reading techniques and which is most suitable depends on the nature of what you are reading and why you are reading it. The main techniques are easily summarised.

\section{Scanning}

This is a technique where we simply focus on the main headings and sub-headings which are listed as an initial guide to the relevance of the material covered. In other words scanning is used to identify those sections which require more careful attention.

\section{Skimming}

This technique involves reading material quickly and is useful when we are already familiar with a topic and simply require a different approach to a topic or a different set of examples. Using this technique it is often possible to skim two or three pages a minute.

\section{Detailed Reading}

This is reading undertaken to build up knowledge and understanding of the subject. By comparison with the other techniques of reading described above, detailed reading is a slow process and requires far more concentration. It is important when reading in detail to adopt an analytical approach. You will derive greatest benefit from detailed reading when you question what you read. For example, when you read a particular argument try and identify the circumstances necessary for the argument to hold, try and think up examples to illustrate points you read about and so on.

\section{Note-taking}

Compiling a set of notes is essential if you are to derive full benefit from the material you read. However notes should be just that, a summary of what you have read. There is sometimes a great temptation simply to rewrite what has been read. In fact this takes considerable time, leads to a copious set of notes that are less useful than the book from which they were taken and in no way improves understanding of the subject. Try to compile a set of notes which summarise in your own words what you have read.

\section{Writing an Assignment}

During your course you will almost certainly be required to produce several assignments. In general it is important to complete work in good time. Rushed work seldom reflects an individual's ability. Before writing an assignment it is usually best to plan what you intend to do in the assignment and how it will be organised. Ideally the plan should cover the whole assignment. A plan should include only the amount of detail necessary for you to remember all of the points you intend to include in your assignment. Having completed your plan it is a good idea to refer to the title of your assignment and check that your plan actually covers all of the relevant material and provides a suitable answer to any questions posed. 


\section{Preparing for the Examination}

\section{Revision}

How and when to revise are matters of individual judgement. However, for most people it is better to regard revision as an on-going process: something that begins when the course starts! Revision in this sense implies paying particular attention to those parts of the course you have difficulty with or which you do not fully understand. This is particularly important in a subject like economics where topics interrelate so that an understanding of one topic is necessary for an understanding of others. For example, economists use supply and demand techniques to explain the behaviour of markets. If these concepts are imperfectly understood it will be difficult to understand the behaviour of the different markets covered by the syllabus you are following.

A solid body of knowledge and understanding takes a considerable time to build up. It is not something that can be achieved in the few weeks before an examination. Final revision should be seen more as a consolidation phase when knowledge and understanding are strengthened. A useful idea before final revision begins is to draw up a revision plan. This should identify the specific times in the run up to the examination when different topics will be covered and understanding checked. One important point to remember is that revision will almost certainly take longer to complete than you anticipate. The further into your revision you go, the more difficult it will be to make progress. In other words be sure you begin revision early enough, so that you have sufficient time to cover the whole syllabus.

As part of your revision programme it is important to practise answering questions from past examination papers. Make sure you have plenty of practice at answering all of the different types of questions (multiple choice, data response, essay and short answer questions). If possible it is a good idea to have these marked by your teacher but this may not always be easy, especially if you are part of a large group. If it is not possible, ask your teacher for a few hints about the way different questions might be tackled and reassure yourself that you are thinking along the correct lines.

It is also useful to obtain the chief examiner's reports on past question papers. These give a good indication of what the chief examiner was looking for in the responses to the different questions, but also gives a guide to the standard required for success in the examination. Possibly of even more importance is that the reports provide information on the most common errors made by candidates in the examination. Few of us are immune from such errors. The more information you have on the mistakes most commonly made, the better your chances of success.

\section{In the Examination}

When you are told to begin the examination it is important to read the question paper fully before you respond to any questions. Indeed it is a good idea to read the question paper more than once and think about what each question is asking you to do. Experience confirms that on a second reading, questions which seemed difficult are often easier than they appeared.

Before you begin your response to any question make a brief plan of what you will include in your answer. Pay particular attention to key words that indicate the type of approach required. Some of the more common key words are explained below.

Briefly or Outline These words tell you that a sentence or a few sentences are all that is required for this part of the question. As your guide, look at the number of marks that are available for an answer to questions that begin with these words. Sometimes all that is required is a straightforward definition of a particular term or concept. At other times a little more explanation is required.

Explain or Analyse These words ask you to demonstrate that you understand how concepts relate to one another and the assumptions that underpin a particular argument. For example, a phrase economists often use is 'other things equal'. Being able to identify these other things and understanding what might happen if they do not remain equal is an analytical skill.

\section{Assess, Evaluate, Discuss or Examine} Questions which include these words require a balanced approach. Reasoned judgements must be made about different arguments and their possible validity assessed. Where appropriate it is important to consider advantages and disadvantages and your points must be supported by argument.

Illustrate This simply means 'explain with examples'. Since you are asked to include examples in your explanation it is important that you do so. Failure to include examples will no doubt result in lost marks. 